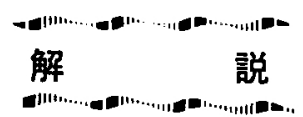

我が国のスペースプレーン*1

一一次世代有人宇宙輸送システム計画

舞田正孝*2

Key Words : Spaceplane, Hypersonic Flight, Airbreathing Propulsion

1.はじめに

我が国の宇宙開発は，国際地球観測年（IGY，1957 年）のロケットによる上首大気観測に始まって以来， 通信, 気象観測、科学観測・探查等の分野の衛星の開 発，および打上げロケットの開発において相応の実力 を身につけ，現在では今後の宇宙空間の広範な利用を 可能とする宇宙ステーションの国際共同作業に参加し て我が国の実験モジュール（JEM）を開発することと しており，先般，宇宙ステーション協力協定(IGA)の 署名も実施された．また，1990年代における衛星需 要に対応し，2 トン級の大型静止衛星を打ち上げる能 力をもつ H-IIロケットの開発により．国際的水準の 自主技術基盤が確立されるとともに自在な貨物打上げ 手段を手にする見込みである。

一方において，世界の宇宙開発は今や月から惑星探 查へとその領域を拡大し，その活動も限られた先進国 から開発途上国へ拡がるとともに，高度多様な宇宙開 発利用の進展が見られ，またとくに欧米を中心に宇宙 活動の商業化へも発展しようとしている.

こうした宇宙開発をめぐる国内外の諸情勢の急速な

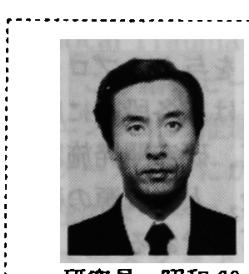

著者紹介

製田 正素(正会員)

昭和 23 年生. 東京都出身. ス夕 ンフォード大学大学院航空宇宙学科 修了昭和 51 年科学技術庁航空宇 宙技術研究所. 昭和 $58 \sim 59$ 年米国

NASA/スタンフォードJIAA 客員 研究員. 昭和 60 62 年科学技術庁研究開発局宇宙企 画課長補佐. 現在, 航空宇宙技術研究所熱流体力学部 主任研究官. STOLプロシェクト,スペースプレー ンシステム等の研究に従事. AIAAメンバー、工学 博士.

*1 平成元年 3 月 2 日原稿受理 On the Japanese Spaceplane -Perspective on the Next-Generation Manned Space Transportation System R \& D

*2 航空宇宙技術研究所 Masataka MAITA
進展，変化に対応して, 昭和 62 年 5 月, 宇宙開発委 員会の長期政策愍談会は，21世紀を展望し，長期的 ビジョンに立った我が国の宇宙開発のあり方につい て，「宇宙開発の新時代を目指して」と題し報告を行 った"

この報告は，我が国の 30 年の宇宙開発の歴史の上 に、今後の 20 年間の長期的方針を提案している.「我 が国は自主的な宇宙活動を自在に展開しうる技術基盤 を早急に構築し」，「今世紀内の努力により，21 世紀 初頭において世界の宇宙開発における中核的一翼とな ることを目標とすべき」と謳い，「宇宙フロンティア の開拓」と題し，むこう 50 年の長期ビジョンを展開し た米国ペイン報告 (The Report of the National Commission on Space $)^{2)}$ にも比厓しうる,きわめて 意欲的な報告である。

この実現に向けては、これまでにない大規模な技術 開発の推進が不可欠であり, 科学探査, 通信・放送. 地球観測，宇宙環境利用，宇宙資源のエネルギー探求 等の宇宙活動の展開はもとより, 有人宇宙活動の展開 とこれら宇宙開発・利用を支える恒久的宇宙施設およ びこれらに容易にアクセス可能な宇宙輸送手段として の宇宙インフラストラクチャーの整備が求められる.

こうした宇宙新時代を支える宇宙インフラストラク チャーに扔いて，地上と宇宙を結ふ有人宇宙輸送シス テム，すなわちスペースプレーンは，最も基本的な要 素の一つである．その実現には高度な技術研究開発の 推進が必要であることから，科学技術庁研究開発局 は, 我が国としてふさわしいスペースプレーンの概 念, 研究開発の基本的推進の道筋等について検討を重 ね，スペースプレーン検討会報告としてとりまとめた (昭和 62 年 6 月) ${ }^{3)}$.

本稿においてはこれらの検討等を踏まえ，スペース プレーンの基本的考元方，およびその実現の前提とな る技術課題と研究開発の方向などについて解説を試み たい. 


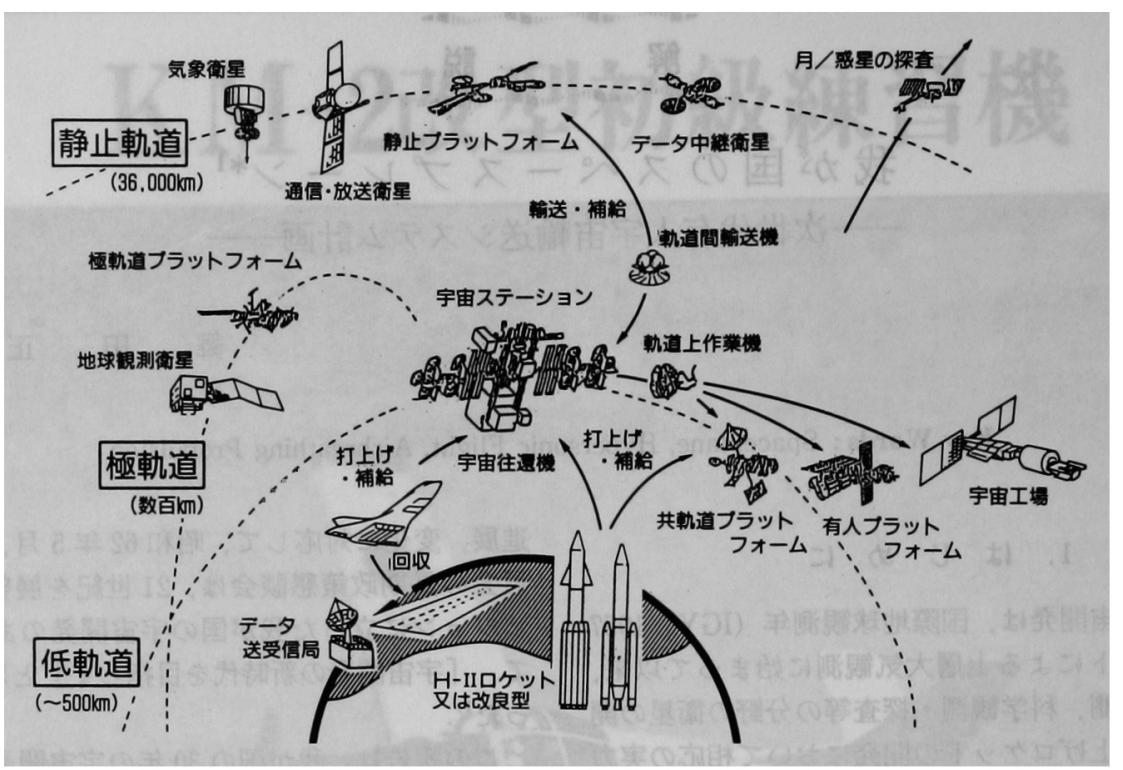

第 1 図 我が国の宇宙開発・利用の展開”

\section{2. スペースプレーンの基本的考え方}

我が国の宇宙輸送システムのあり方，とりわけ有人 宇宙往還輸送システムの構築を課題として討議された スペースプレーン検討会の報告を踏まえ，次世代の有 人輸送システムすなわちスペースプレーンの基本的な 考え方は，以下のようにまとめられる

(1) 今後の宇宙輸送システムの開発にあたっては， 明確に「有人輸送と無人の貨物専用輸送について 機種を分離」すべきこと，すなわち，人間の輸送 にあたっては，安全性，信頼性の確保を最優先 し、さらには人間にとっての快適性, 経済性が重 要視される，一方, 物資の輸送については，大量 の物資を低コストで効率よく輸送することが基本 となる。

（2）有人宇宙輸送システムの目標としては，「安全 で信頼性・運用性が高く，技術的にも経済的にも 将来発展のあるシステムとして，航空機なみの十 分な安全性, 運用の自在性をもった有翼・水平離 着陸方式の再使用型有人機（「スペースプレーン」 という)」であること.

(3) スペースプレーン開発においては，宇宙およひ 航空技術基盤の高度化，総合化とともに，新素 材，エレクトロニクス等，広汎な高度先端技術の 結集が求められるが．この推進に際して我が国は 「基盤技術の育成と確立，運用にあたっての自在 性を念頭に扔き独自のプロジェクトとして推進」 するとともに国際協力について，「研究開発の初
期の段陼から柔軟に配虑」しつつ，国際共同開発 においても「我が国のデザイン・オーソリティを 確保」すべきであること．

（4）21 世紀初頭の実験的運用を目標に，計画段陵， 実験・実証段階およびプロトタイプ開発段陵にフ エーズ分けした段階的研究開発計画に基づき着実 に推進.（オペレーショナルな運用段階の）スペ ースプレーンの開発は、これら段階的研究開発の 過程で獾得される技術基盤をもって次に進むもの とする．また，スペースプレーン実現に必要な技 術と，その後の実際的な開発段陼にまで成热させ るには地上での十分な試験と実験機による技術実 証が不可欠である.

(5) プロトタイプ開発段階までにおよそ2 兆円と見 込まれるスペースプレーン計画は，大規模で経済 的, 社会的に大きなインパクトを与えるプログラ ムであり，この推進にあたっては，各段階に応じ た有効な実施体制の整備・拡充，研究開発施設・ 設備の開発・整備ならびに資金, 人的資源の確保 等の条件整備を図ることが不可欠である。

次世代の宇宙輸送システム構築においては，(1)の貨 客分離の立場をとったことはきわめて重要である。こ の基本的考え方の背景には，米国のスペースシャトル の開発・運用等の過程が, 有益な示唆となっている.

米国における宇宙往還機構想は，1950年代初期に すでに当時の NACA ラングレーで現在の極超音速有 翼機に近い概念が検討されていたところてあるが、ソ 連の Sputnik 打上げ成功による危機意識が米国をし 


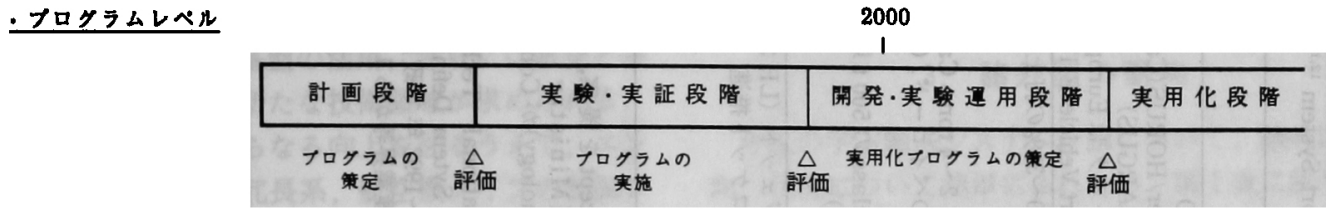

\section{・フロシェクトレベル}

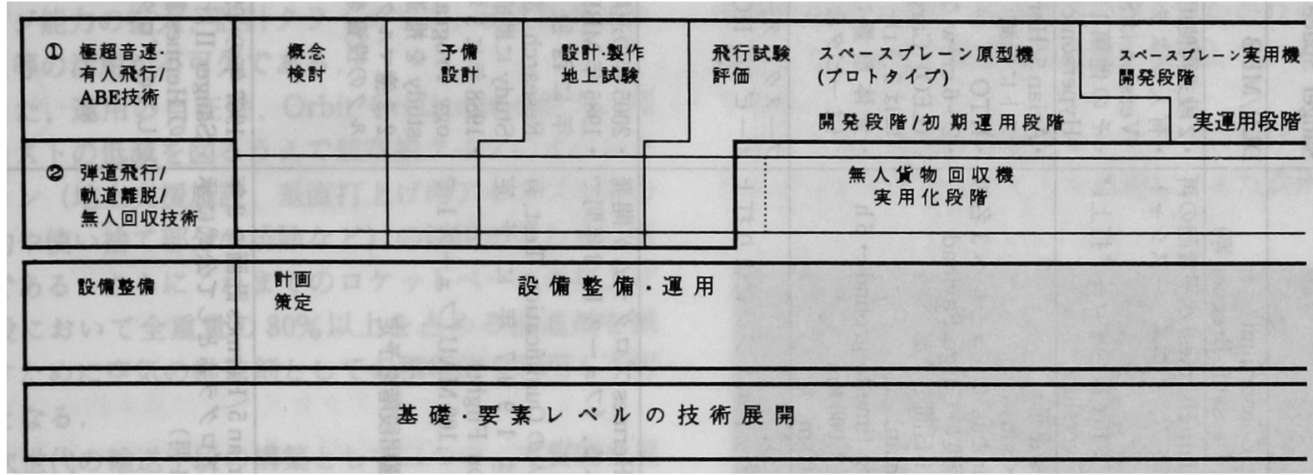

第 2 図 スペースプレーン研究開発計画 ${ }^{3 \prime}$

て、いかなる手段においても早期に人を宇宙に送るこ とを求めたこともあり，米国の最初の有人飛行は有翼 回収機ではなく輸送カプセル回収となった。もちろん この技術的背景には，当時十分に強力な推進エンジン の開発がこのスケジュールにのらなかったことも原因 するn.

その後，再使用型回収機計画として 1960 年代後半 加 ILRV (Integral Launch and Recovery Vehicle) プログラムが検討され，1969 年に NASA のプロジェ クトとしてスペースシャトル計画の開始となる。スペ ースシャトルも当初は完全再使用型の 2 段式回収機 (TSTO) として計画されたが，その後のいわゆる “Political Trauma”により，開発コストは大幅に削減 され，この結果ビークルの規模も縮小し，オービター の主エンジンの推進剤は外部タンクにおき，フライバ ックプースターにかわり固体ロケットプースターとす る現在のスペースシャトルの形態へと変更される ${ }^{8)}$.

スペースシャトルの低軌道への打上げコストは 3,000 ドル $/ \mathrm{kg}$ とされているが、これは，使い捨て部 分の外部タンクならびに固体ロケットブースターの再 取付け等の再使用性のないハードウェア部分が全体コ ストの 40\%以上を占め，またオペレーション経費も 飛行オペレーションおよひ地上オペレーション, ター ンアラウンド，ミッション中の地上支援要員（1万人 を越えるスタッフ)，支援施設などで $40 \%$ を占める．

また，スペースシャトルの輸送ミッションとして，
相当部分の貸物が宇宙ステーションの建設および消耗 品の片道輸送であるのに，たとえば宇宙実験室である Space Labまで持ち㷌る設計としたため, ペイロー ドの占める割合が小さくなり，打上げコストを上げる 結果ともなった。

また，運用コストの問題以外にスペースシャトルの システムにおいてはターンアラウンド・タイムの問題, 運用の自在性等についての制約が指摘されるに至つ た。

スペースシャトルは，人と物資の輸送を兼ねたシス テム設計であるための，高い信頼性や生命維持のため の複雜な機能要求と物資輸送のコス卜低隇化要求との トレード・オフにより，結果的に開発費，運用蒷とも 高価なものとなり．それぞれのミッション要求を一つ の技術システムのなかで実現し，全てを満足させるこ とがきわめて困難であることの例としてとらえること ができる.

貨客分離の考え方は，また，物資輸送として optimizeしたビークルに，有人輸送機能をもたすこ とに付随する開発、運用コストが，結果的には正当化 されないという示唆とも言えよう。

(2)に述べた基本的考方方は, 次世代のスペースプレ ーンが安全性, 信頼性の確保, 運用の自在性そして運 用コストの低減を目指すこととして要約される.

我が国の宇宙開発において，これまでの無人の宇宙 活動という開発基盤から有人宇宙活動へと展開がなさ 


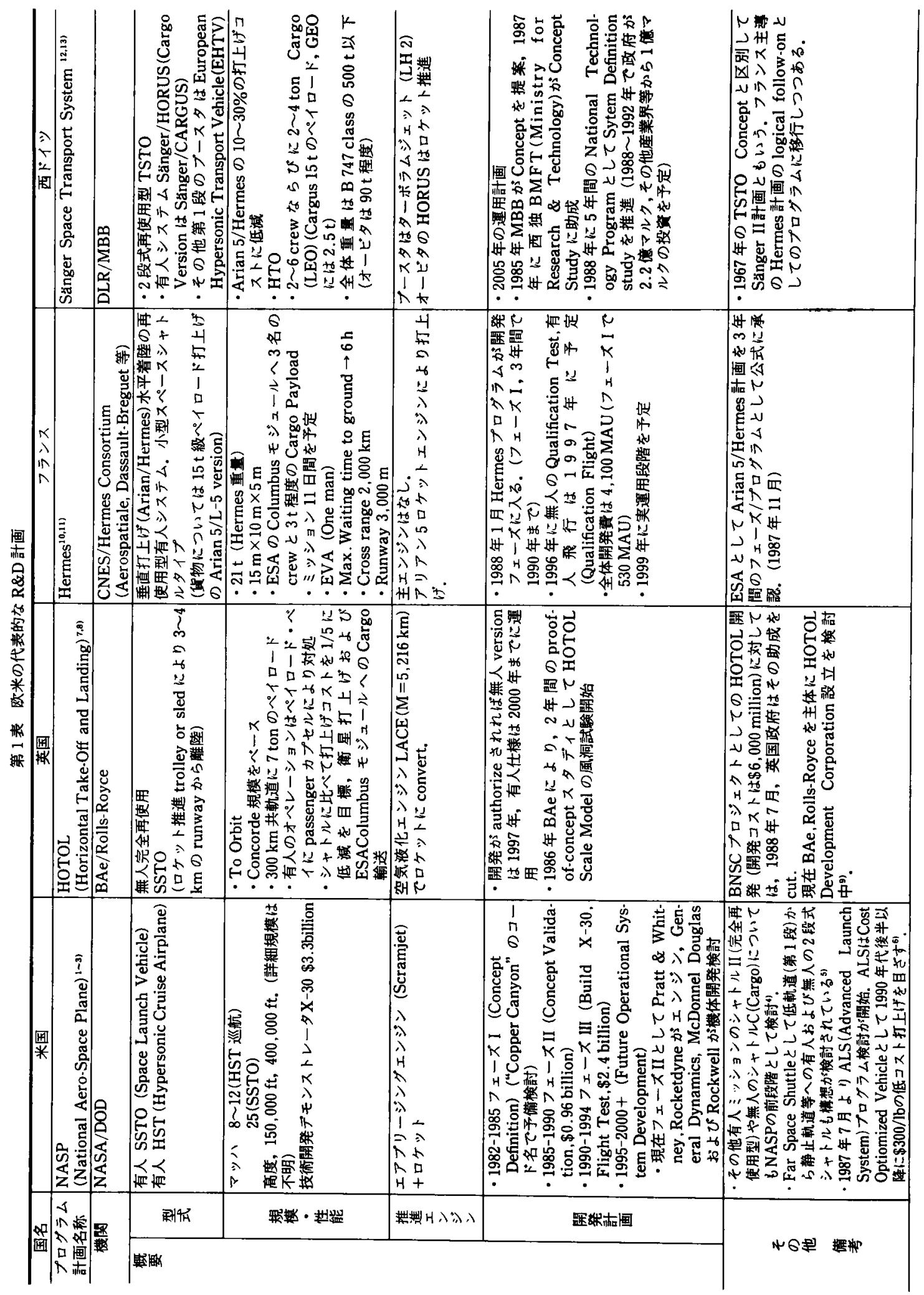


れるとき、これまで 70 年余にわたる有人輸送の視点 に立脚する航空の技術基盤の活用，さらには航空と宇 宙技術との融合という新たな技術領域が求められる.

安全性，信頼性のさらなる向上を図るうえで，エン ジン故障を前提とした冗長系, 航空機タイプの制御シ ステム、翼による空気力の利用による推力重量比 (thrust loading) の低隇, 飛行アボート能力, クロス レンジ能力の拡大, 設計クライテリア, 研究開発プロ セス等の活用が不可欠である.

また，運用の自在性，Orbit On-Demand 能力，運 用コストの低減を図るうえで航空機タイプのオペレー ション（地上支援施設，垂直打上げ用アセンブル塔の 制約や使い搭て部分の排除など）の活用がきわめて有 効である.さらにこれまでのロケットベースの打上げ 手段において全重量の $80 \%$ 以上を占める推進剂を減 らすために空気の推進剤としての積極的な利用も不可 欠となる。

次世代の輸送手段の構築として二つの，本質的に異 なる互いに補足しあうアプローチがあると思われる。 その一つは新しい概念と技術の導入により革新的なシ ステムを構筑する方法であり．他の一つは既存のシス テムをべースにしてシステマティックな設計改良と発 展的開発により信頼性とコスト低減につなげる過程で ある．我が国において次世代の有人システムを考える とき前者の考え方に基づく概念と技術の革新によるシ ステムの発展性に着目すべきであり，係るシステムの 実現に向けてシステマティックな技術開発プログラム
を具体化すべきである。

\section{3. 諸外国の動向}

今後の宇宙輸送システム計画について, 諸外国の動 向，状況について簡単にふれたい. 第 1 表に欧米の関 連する計画およびその現状をまとめた 27).それそれ 詳細は表中の説明を参照されたいが，先進諸外国は宇 宙開発を国の威信，経济発展の成否にかかわる重要問 題として，独自に積極的な政策を推進しているところ である。

すなわち，米国は宇宙フロンティアにおける世界の リーダーシップをとることを目指し，また欧州は米国

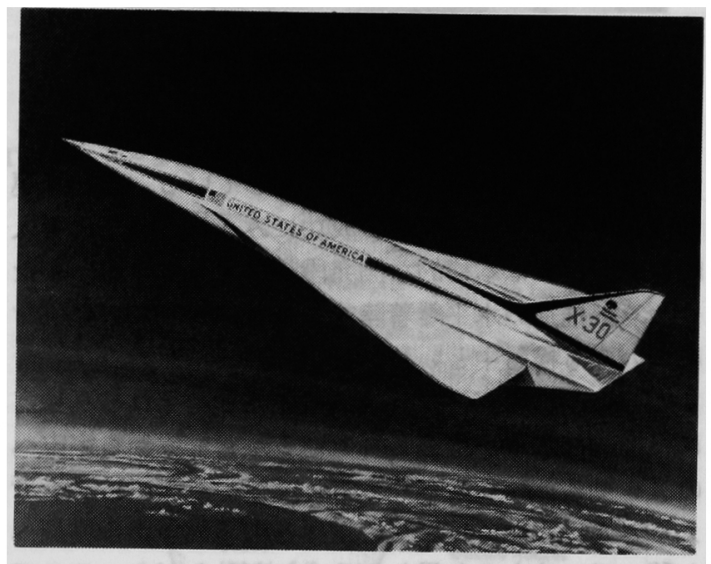

第 3 図 米国 NASP 計画一X30 実験機一

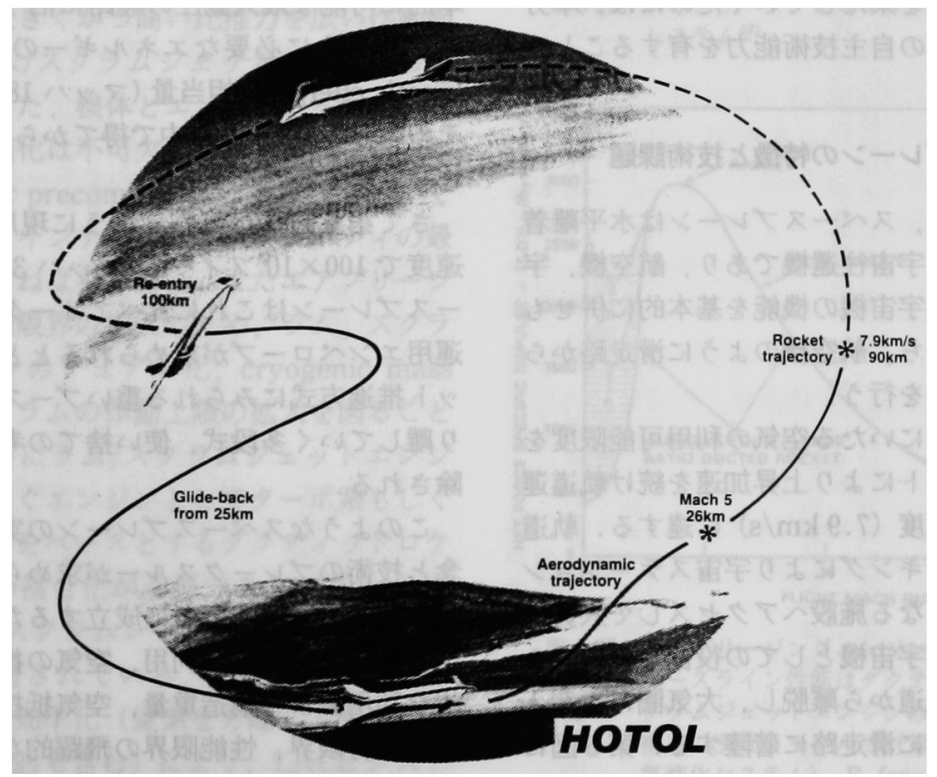

第 4 図 英国 BAe/Rolls Royce HOTOL 


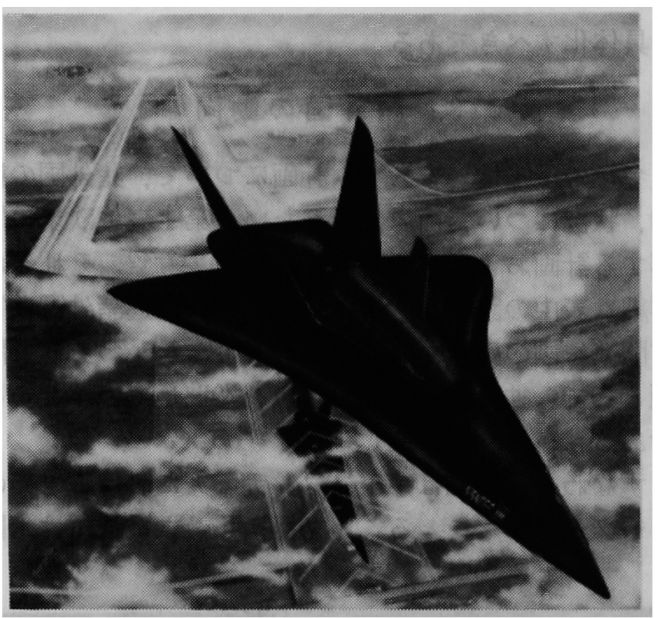

第 5 図西独 Sănger II

に依存しない独自の地歩を確保し，欧州独自の宇宙イ ンフラストラクチャー構築を目指している．またり連 についても，ブラン開発の成功にみられるように有人 渝送システムは本格的な開発段階に入っている．また ロケット推進の水平離着陸式エアロスペースプレーン についても検討中といわれる18).

このように現在，諸外国においては，それぞれ独自 に積極的な政策が推進されているが，地球から宇宙へ のアクセスというスペースプレーンの本質的役割を考 えるとき，やがては現在の世界各国の競争から協調へ と移っていくものと思われる。しかしながらここで 重要なことは，前章にも指摘されるように，その際， 我が国が積極的な役割を果たしていくためには，本分 野において国際的水準の自主技術能力を有することが 不可欠である。

\section{4. スペースプレーンの特徽と技術課題}

2 章で述べたように、スペースプレーンは水平離着 陸方式の再使用型有人宇宙往還機であり，航空機, 宇 宙輸送機および軌道上宇宙機の機能を基本的に併せも つものである.すなわち，航空機のように滑走路から 水平離陸し, 加速上昇を行う。

垔音速から極超音速にいたる空気の利用可能限度を 越えたのちは，ロケットにより上昇加速を続け軌道運 動に必要な第 1 宇宙速度 $(7.9 \mathrm{~km} / \mathrm{s})$ に達する。軌道 上ではランデブ・ドッキングにより宇宙ステーション 等, 有人活動の拠点となる施設へアクセスして人員の 供給・支援を行うなど宇宙機としての役割を担い，ミ ッション達成後は，軌道から離脱し，大気圈に再乫入 して再び航空機のように滑走路に着陸する. 第 6 図に このような飛行形態をとるスペースプレーンの代表的

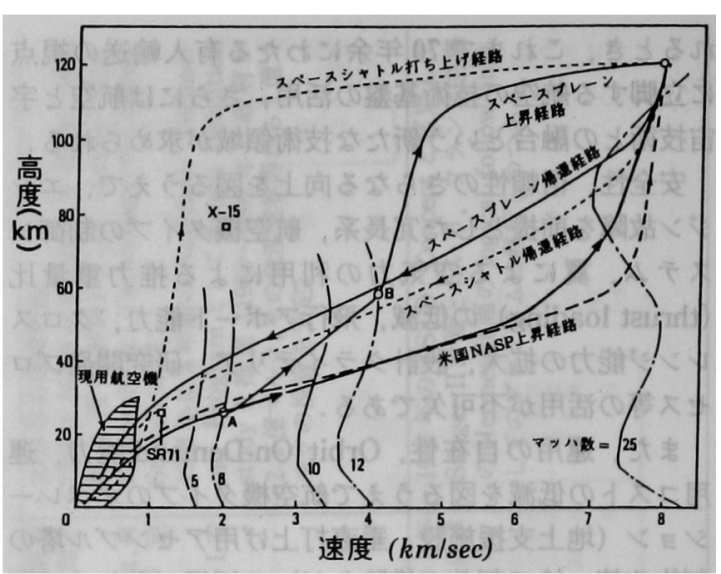

第 6 図 スペースプレーンの代表的飛行経路

な飛行経路を例示した。

これまでの宇宙へのアクセス手段は基本的にロケッ ト推進によるものであるが，この基盤に立ったスペー スシャトルの軌道投入への経路との相違は明らかであ る. ロケット推進の場合, 空気の存在はビークルの抵 抗として作用する以外は，ロケットエンジン推力への 影響をほとんど無視できるから，ロケット推進による 基本的な飛行方式は，はじめに高度を主体にとり，大 気密度が十分小さくなってから，加速フェースに入 る.一方スペースプレーンのようにエアプリージン グ・エンジンによって推進される vehicle では, その エンジン推力が大気の密度等に大きく依存することか ら，機体の熱的/空力的な性能限界，制約条件下で基 本的に可能な最大動圧の経路に沿って加速し（すなわ ち軌道投入に必要なエネルギーのほとんどを占める kinetic energy の相当量 (マッ八 18〜19 までの加速で その半分程度)を大気中で得てから)，次に上昇し軌道 に投入する経路をとる。

さて第 6 図に示されるように現用の航空機の高度/ 速度で $100 \times 10^{3}$ フィート/マッハ 3 程度である．スぺ ースプレーンはこれに比へてオーダーとして一桁高い 運用エンベロープが求められるとともに，通常のロケ ット推進方式にみられる重いブースト段などを順次切 り離していく多段式，使い捨ての考え方は基本的に排 除される。

このようなスペースプレーンの実現には，新しい概 念と技術のブレークスルーが求められる.スペースプ レーンがシステムとして成立するためには加速上昇時 における, 空気力の利用, 空気の推進剤としての積極 的な利用および構造重量, 空気抵抗の大幅な軽減等に よる飛行限界，性能限界の飛躍的な拡大が不可欠であ り.このためには、エアープリージング・エンジンお 


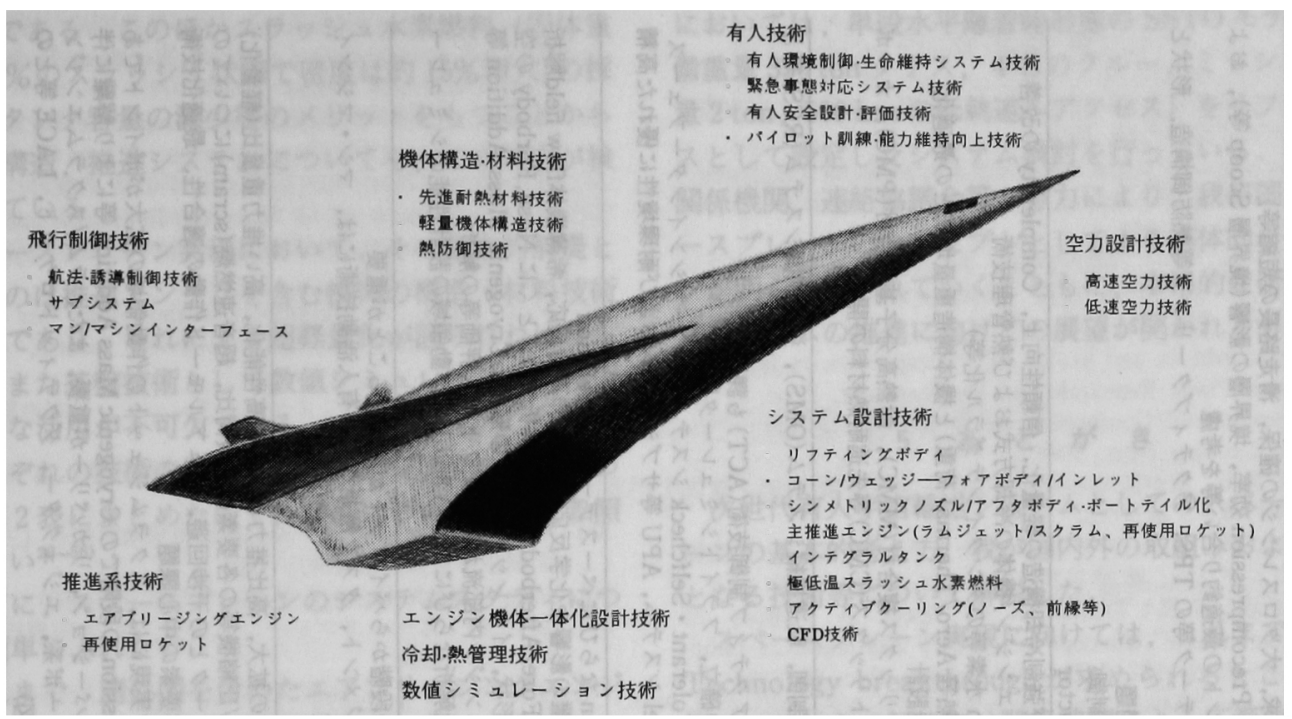

第 7 図 スペースプレーン(SSTO)のイメージと技術課題

よびロケットエンジン技術、超軽量機体構造，超高温 耐熱材料技術，離着陸/最適軌道の誘導制御技術，機 体空力形状，エンジン機体一体化技術，などの革新技 術ならびにこれら技術の最適システムインテグレーシ ヨンが主要な課題となる。

第 7 図にスペースプレーンの概念イメージと代表的 な技術課題を示した。

推進システムとしてエアブリージングエンジンはス ペースプレーンの形態を決定する最大の要因の一つて ある.とくにSSTO 方式のスペースプレーン実現に は，推力重量比が大きくかつ高い比推力を広い作動範 囲で可能とするラム/スクラムジェットエンジンの実 現が求められる.また，機体とエンジンのインテグレ ーションによる最適化は不可欠であり，有奻な空気の 取りこみ，効率的な precompression を実現する上で 機体フォアボティ、インテーク，アフターボディの最 適空力設計がなされねばならない。またエアブリージ ングエンジンの作動限界の拡大のため，ラム、スクラ ムジェットエンジンのデュアル化, cryogenic mass の付加等によるスクラムの作動上限の拡大を図ること も重要である.さらにラム/スクラムジェットエンジ ンの作動域までつなぐエンジンとしてターボ系もしく はロケットエンジンをベースとするダクティッドロケ ット．LACE 等との複合化が必要であり（第 8，9図 参照)，たとえば，スクラムレースエンジンはその有 力な候補として検討されている. LACEについては 空気液化システムの効率化（窒素を分離して酸素を液 化するシステムの検討も含む）により，LACEシステ ムのみによるSSTO 成立の可能性の追求も重要な検

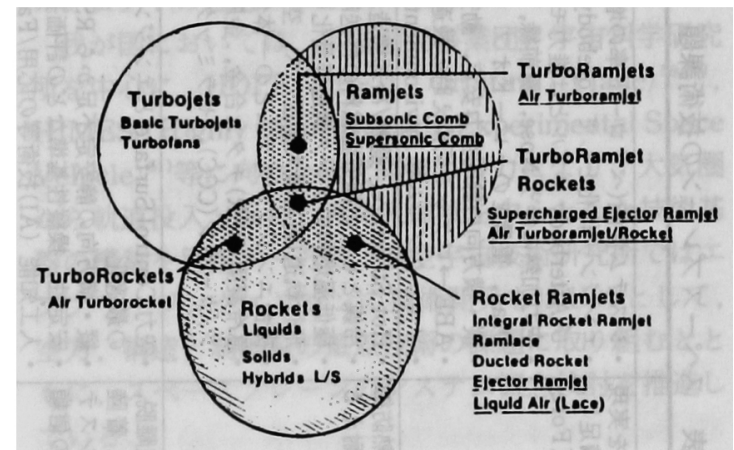

第 8 図 エアブリージングエンジンの基本サイクルと複合 システム゙8)

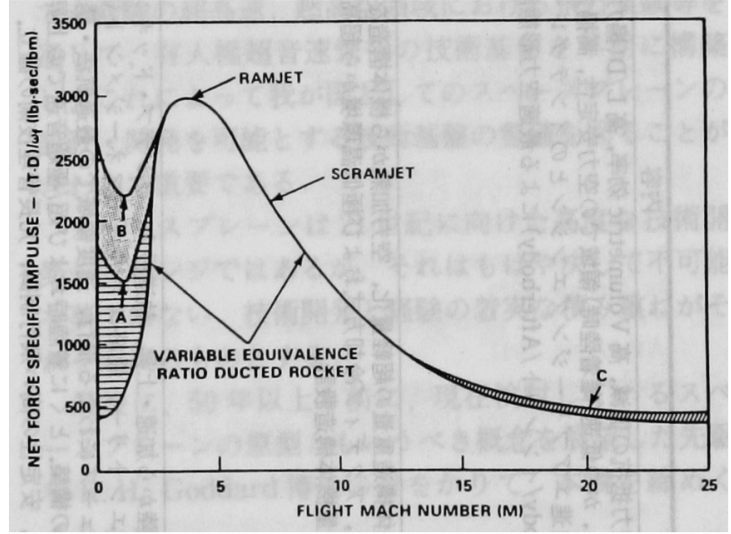

第 9 図エアフリリージングエンジン性能50) ペースライン性能はダクティドロケット/ラムース クラムジェットエンジンのサイクルによる有奻比 推力（SSTO モデルで計算）。I efr の增加は A (空 気液化システム)，B (cryo-cooled コンプレッサ - ). C (oxygen $\sigma$ 付加) 


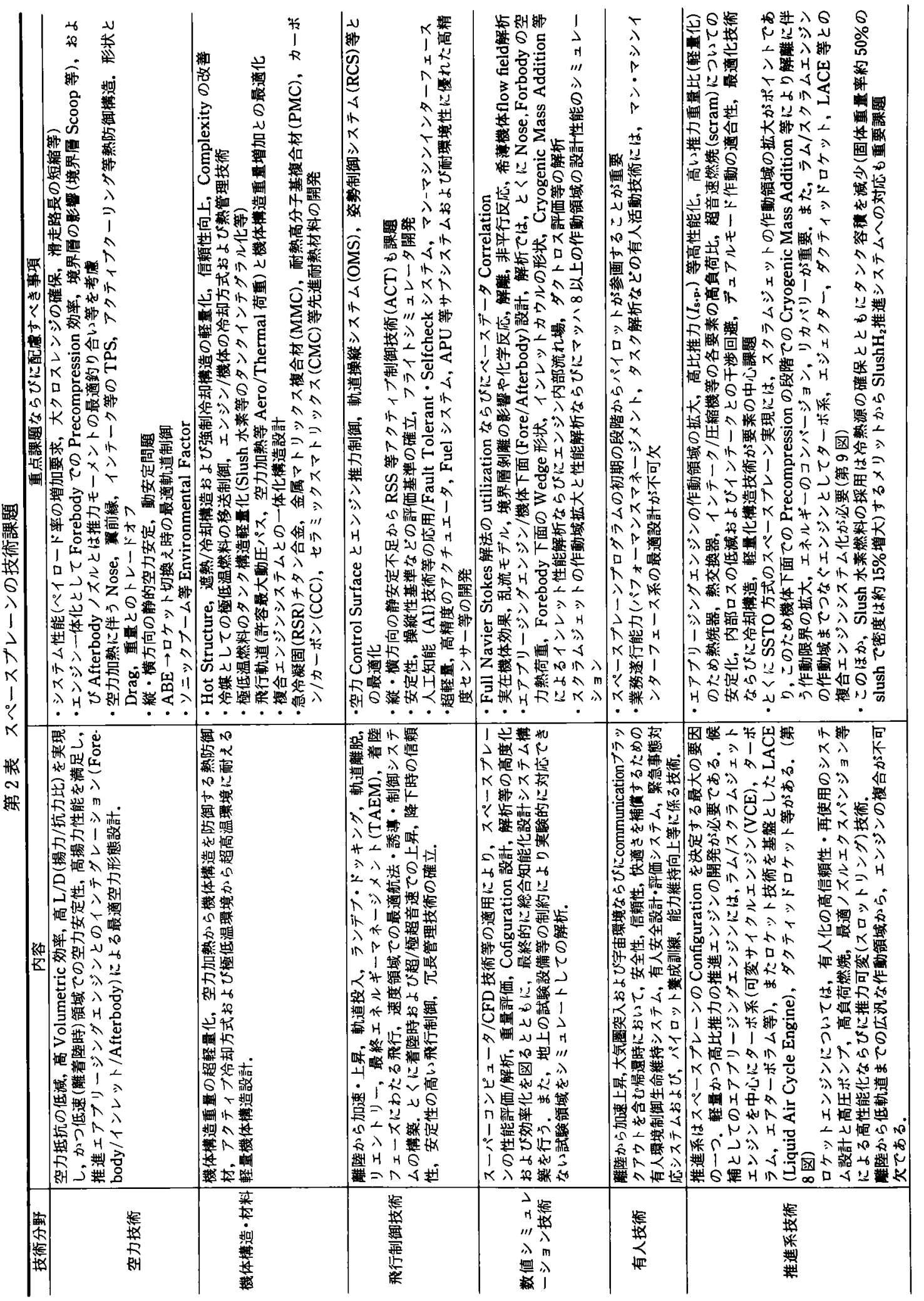


討課題である.このほかスラッシュ水素燃料（固体重 量率 50\%のスラッシュ状態で密度は約 15\%増大)の採 用は、タンク容量の減少等のメリットをもつことから タンク構造，推進システムについても，この対応が検 討されている.

スペースプレーン実現において，その基本的前提と なるものは推進エンジンを含む機体の構造・材料技術 の革新であり。これによる超軽量化が図られねばなら ない。 また基盤技術として数値シミュレーション技術 の有効な活用が不可欠である.

それそれの技術の概要，課題と研究開発の方向につ いて第 2 表にまとめたので, 詳細については表を参照 されたい2 ${ }^{28-56)}$.

つぎに、スペースプレーンのシステムスタディにつ いて簡単にふれたい

これまで、諸外国を含めたエアブリージングエンジ ン推進方式のローンチビークルの検討は，米国ての Goddard（1933 年)，西独 Sänger（1956 年)等以来技 術検討がなされてきたものであり，決して新しいこと ではない.

これまでの検討の多くは 2 段式水平離着陸方式 (TSTO)が中心であったが, これはステージングによ るぺイロード率の増大ということもさることながら， 検討時におけるエアブリージングエンジンの作動, 性 能限界や先端材料, 構造設計の重量低減化ポテンシャ ル等によることも多い：さて，我が国においてはスぺ ースプレーン検討会報告をうけ，スペースプレーン研 究開発プログラムについて具体的，技術的な討議を行 うため，航空宇宙技術研究所，宇宙開発事業団および 宇宙科学研究所が中心となって産学官の連携の下に， 「スペースプレーン研究開発連絡協議会」(昭和 62 年 7 月）が設置され，この協議会の下にプログラム，機体 およびエンジンの各分科会を設け，スペースプレーン のシステムコンフィギュレーション，推進システムの 評価/検討, 研究開発プログラマティック等の検討が 行われている57. スペースプレーンシステムスタディ

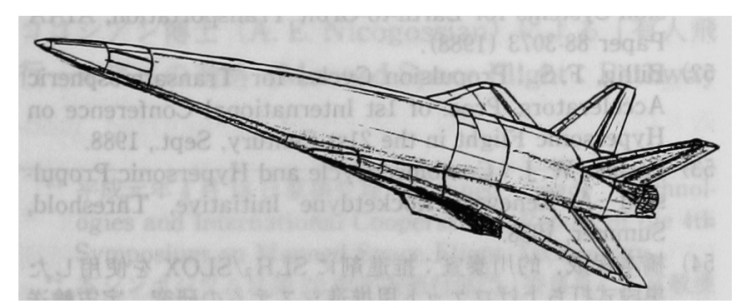

第 10 図 SSTO コンセプトスタディ スペースプレーン連絡協㦈会/航空宇宙技術研究 所、スケッチ絵は Harry Scott の Courtesy
においては，単段水平離着陸形態のSSTO モデル（全 㣁重量 350 tonクラス, 4 名のクルー, ミッション重 量 2 ton, $500 \mathrm{~km}$ の低軌道へアクセス) をリファレン スとして設定したシステム検討を行っている。これら 関係機関、連絡協議会等の努力により，我が国のスペ ースプレーンのコンセプトとしてより具体的なイメー ジが明らかにされていくとともに，本格的な研究開発 プログラムの推進に向けての展望が開かれるものであ る。

\section{5. あとがき}

次世代有人宇宙輸送システムとしてのスペースプレ ーンの基本的考え方, 我が国内外の取組みおよび課題 となる技術等について解説した。

スペースプレーン実現に向けては，これまでにない Technology breakthrough が求められるところであ るが、これらの解决には関係機関による広範な研究プ ロジェクトの推進による技術開発が不可欠となる.

我が国においては, 宇宙開発事業団, 宇宙科学研究 所を中心に, HOPE (H-II Orbiting Plane) ${ }^{59,60)}$. HIMES (Highly Maneuverable Experimental Space Vehicle) $)^{61)}$ 等に向けた研究開発の努力により, 大気圈 から軌道投入 - 保持, 再突入領域を中心とした技術基 盤の構築を目指す一方で，航空宇宙技術研究所ではエ アブリージングエンジンの技術開発をはじめとして， 空力, 構造, 制御系の重点技術の課題に取り組むとと もに、スペースプレーンのシステム概念検討を推進し ている。

今後，我が国としてはとくに，離着陸および大気圈 内での加速上昇等の技術領域を中心に，我が国にとっ て未経験の超高速, 超高空領域における飛行実験等を 通して，有人極超音速飛行の技術基盤を早期に構築 し，これによって我が国としてのスペースプレーンの 設計・開発を可能とする技術基盤の整備を図ることが きわめて重要である.

スペースプレーンは 21 世紀に向けた高度な技術開 発チャレンジではあるが、それはもはや決して不可能 な夢ではない，技術開発と経験の着実な積み重ねがそ れを現実のものとする。

最後に，50 年以上も前に，現在検討しているスペ ースプレーンの原型ともいうべき概念を展望した先駆 者R. H. Goddard 博士の言をかりて，本稿を締めく くりたい

"The dream of yesterday is the hope of today and the reality of tomorrow." 


\section{参考文献}

1）宇宙開発委員会長期政策琹談会（座曼，斉藤成文宇宙開発 委員会委員長代理）報告.

2) The Report of the National Commission on SpacePioneering the Space Frontier, Bantam Books, New York, May, 1986.

3）スペースプレーン検討会報告、科学技術庁研究開発局スペ 一スプレーン検討会 (座長，小林繁夫東京大学教授) 昭和 62 年 6 月.

4) Kobayashi, S. and Maita, M. : Perspective on Japanese Space Plane Research and Development, Proc. of 1st International Conference on Hypersonic Flight in the 21st Century, Sept., 1988.

5）小林繁夫：我が国のスペースプレーンの政策/展望，第 26 回飛行機シンポジゥム、1988.

6）舞田正孝：スペースプレーンのシステムスタディと研究開 発プログラム，第 26 回飛行機シンポジウム，1988.

7) Hansen, J. R. : Transition to Space : A History of "Space Plane" Concept at Langley Aeronautical Laboratory 1952-1957, J. Brit. Interplanet. Soc., 40 (1989).

8) Scott, H. : Space Shuttle Orbiter Configuration Case History, AIAA Paper 78-1569 (1978).

9) Williams, R. M. : NASP : Technology for America's Future, Aerospace Am., Nov (1986).

10) Tortolano, F. W.: Birth of a Space-Age Plane, Aerospace, April (1988).

11) Voelcker, J. : The Iffy Orient Express, IEEE Spectrum, August (1988).

12) NASA LRC : Space Transportation System beyond 2000, IAF-87-188, 1987

13) Pland, W. M. : Technology Challenges for the National Aero-Space Plane, IAF-87-205, 1987.

14) Branscome, D. R. : NASA Launch Vehicles-Next Twenty Years, IAF-88-189, 1988.

15) McDonnell Douglas : Program Development-National Aero-Space Plane, 1988.

16) Bekey, I. : Potential Directions for a.2nd Generation Space Shuttle, Acta Astronaut., 17, No. 9 (1988).

17) Heppenheimer, T.A. : The National Aerospace Plane, Pasha Market Intelligence Press, 1987.

18) GAO : NASP A Technology Development and Demonstration Program to Build the X-30, Report to Congressional Committees, U.S. General Accounting Office, 1988.

19) Salkeld, R. : Far Space Shuttle, Aerospace Am. Nov. (1988).

20) Wolfe, M. G. : The Coming Revolution in Space Transportation, IAF-88-188, 1988.

21) British Aerospace: HOTOL A Future Launch Vehicle for Europe, 1986.

22) Wilson, G. P. : HOTOL Aerospaceplane for Europe, IAF-87-208, 1987.

23) Flight International, pp.54, Sep., 1988.

24) Hermes Program, Directorate of Space Transportation System, ESA, 1987.

25) Capart, I. J. : The Phase 1 of the Hermes Development Program, IAF-88-201, 1988.

26) Koelle, D. E. et al. : Sănger, IAF-87-207, 1987.

27) German Sponsored Hypersonic Activities (1960-1987), Aerospace Research Projects Monitoring, BMFT, 1987.

28) Harsha, P. T. : Integrated Hypersonic Vehicle Design, Lockheed Aeronautical Systems Company, 1987, 12.

29) Nelms, W. P., Jr. : Effect of Body Shape on the Aer- odynamic Characteristics of an All-Body Hypersonic Aircraft Configuration at Mach Numbers From 0.65 to 10.6, NASA TN D.6821 (1972).

30) Agnone, A. M. : Analytical and Experimental Investigation of a Swept 3-D Fixed Geometry Mixed Compression Hypersonic Inlet, AIAA Paper 87-0159 (1987).

31) Gopaluswami, R. et al. : Concept Definition and Design of a Single-Stage-to-Orbit Launch Vehicle Hyperplane, IAF-88-194, 1988

32) Scott, H. A. : A Synthesis Methodology for Hypervelocity Vehicle Design, Rockwell Intern., October (1988).

33）遠藤 治, 野村茂昭：スペースプレーン, 日本の科学と技 術 7-8, 29, No. 251 (1988).

34）久保田弘敏：スペースプレーンの機体技術、第 26 回飛行 機シンポジウム, 1988.

35）スペースプレーンシステムの基整概念検討報告（三菱重工 業/航空宇宙技術研究所)，1989. 3.

36) Entry Vehicle Control, NASA SP.8028 (1969).

37）池内正躬：スペースプレーンの制御，第 26 回飛行機シン ポジウム、1988.

38) Helenbrook, R. G. et al. : Evaluation of Active Cooling Systems for a Mach 6 Hypersonic Transport Airframe, NASA CR-1917 (1971).

39）砂川 惠：スペースプレーン用材料について，第 26 回飛 行機シンポジウム, 1988.

40) Vahl, W. A. et al. : Study of Heat Sink Thermal Protec. tion Systems for Hypersonic Research Aircraft, AIAA Paper 78-38 (1978).

41）スタインバーク，M.A.：航空宇宙分野の新材料．Science, 12 月号 (1986).

42）日本航空宇宙工業会：スペースプレーン開発動向調査， 1988. 3.

43）三好 甫, 田村敦宏：スペースプレーンと数值シミュレー ション技術、第 26 回飛行機シンポジウム， 1988.

44) Hewitt, F. A. : Airbreathing Propulsion for Advanced Orbital Launch Vehicles, IAF-87-266, 1987.

45）鈴木昭夫：推進エンジン，第 26 回飛行機シンポジゥム， 1988.

46) Doublier, M. et al. : Progress in Airbreathing Combined Engines, IAF-87-262, 1987.

47) Czysz, P. : Thermodynamic Spectrum of Airbreathing Propulsion, SAE Tech. Paper 881203 (1988).

48) Kors, D. L. : Combined Cycle Propulsion for Hypersonic Flight, IAF-87-263, 1987.

49) Bendot, J. G. : Composite Propulsion Systems for a Advanced Reusable Launch Vehicle Application, 2nd ISABE, Mar., 1974.

50) Edwards, C. L. et al. : Studies of Scramjet/Airframe Integration Techniques for Hypersonic Aircraft, AIAA Paper 75-58 (1977).

51) Dorrington, G. E. : Optimum Combined-Cycle Propulsion Systems for Earth-to-Orbit Transportation, AIAA Paper 88-3073 (1988).

52) Billig, F. S. : Propulsion Cycles for Transatmospheric Accelerators, Proc. of 1st International Conference on Hypersonic Flight in the 21st Century, Sept., 1988.

53) Escher, W. J. : Combined-Cycle and Hypersonic Propulsion-A Renewed Rocketdyne Initiative, Threshold, Summer, 1988.

54）橋本保成，的川泰宣：推進剂に $\mathrm{SLH}_{2} / \mathrm{SLOX}$ を使用した 単段式打ち上げロケット用推進システムの研究，宇宙輸送 シンポジウム, 1982.

55) Notardonato, J. J. et al. : High Density Propellants for 
SSTO Vehicles, NASA TMX-73503 (1976).

56) Slush Hydrogen Pumping Characteristics, NBS Technical Note 364, National Bureau of Standard, 1968.

57）スペースプレーン研究開発連絡協議会ワークショップ. 1988. 7.

58) Yamanaka, T. : NAL's Research for Hypersonic Flight, Proc. of 1st International Conference on Hypersonic Flight in the 21st Century, Sept, 1988.
59) Ito, T., Akimoto, $T$. et al. : Development Scenario of H-II Orbiting Plane, HOPE, IAF-87-210, 1987.

60) Takizawa, E. : System Concept and Guidance, Navigation \& Control of H-II Orbiting Plane, HOPE, IAF-88$195,1988$.

61）HIMES 飛翔体小研究会：HIMES 飛翔体計画概念, 1987 . 3.

\section{有人宇宙技術と国際協力*1}

第 4 回有人宇宙飛行技術シンポジウム報告

第 20 期宇宙航行部門委員会*2

Key Words : Manned Space System, Crew Training, Space Life Science, Moon Base, Artificial Gravity, International Cooperation

\section{1.はじめに}

第 4 回有人宇宙飛行技術シンポジウムが平成元年 1 月 19,20日の両日，日本学術会議講堂で開催された． 日本航空宇宙学会と学術会議航空宇宙工学研究連絡委 員会の共催に移行してから 2 年目にあたる.今回のシ ンポジウムのメインテーマは「我が国の有人宇宙活動 の将来と国際協力」である. 我が国の国際宇宙ステー ションへの参加が具体化して，日本の実験モジュール (JEM)の開発が始まるとともに，第 1 次材料実験 （FMPT）のための搭乗員の訓練が最終段階に移行す るなど，現行の我が国有人宇宙飛行に関する活動分野 は国際協力が出発点となっているのみでなく，今後の 国際協力の必要性はますます高まっていくものと予想 される.したがって諸外国の有人宇宙技術に関する最 新の情報を得ておくことは常に重要である。

このような視点から今回は, 米国航空宇宙局 (NASA) と西ドイッ航空宇宙研究所 (DLR，旧称 DFVLR）から講演者を招き各国の将来計画を発表し ていただいた，すなわち，NASA 本部の医学部長二 ココシアン博士 (A. E. Nicogossian) による「有人飛 行一未来への進路 (Manned Space Flight : Pathway

*1 平成元年 4 月 18 日原稿受理 Manned Space Technologies and International Cooperation-Report of the 4th Symposium on Manned Space Flight Technology

*2 本シンポジウムは第 20 期宇宙航行部門 (委員長：二宮敬虔 (宇宙研)」が企画・運営を行った. 本報告は部門委員 中島 厚 (航技研)，小野島昇 (日産自動車) が担当し。とりまと めた。 to the Future)」と, DLRのククリンスキー氏 (P. Kuklinski) による「ヨーロッパの宇宙船乗組員の着成 カリキュラム (Training Curricula for European Space Crews)」(いずれも特別講演) である.ククリ ンスキー氏は西ドイッの D1 ミッション（1985 年に打 ち上げられた西ドイツ独自の最初の有人宇宙実験）に 対しフライトサージャンの一人として参加した航空医 学専門家であり，同氏の講演はヨーロッパで計画中 （まもなく建設予定）の搭乗員訓練センターの概要につ いて述べたものである．また日本の宇宙飛行士(候補) 3 人を含め，広い分野の尃門家にお集まりいただい て, 同じテーマでパネル討論会を最終日に行った。 な お，特別講演としては，さらに今井兼一郎氏（日本工 業技術振興協会理事, 日本学術会議会員）による「我 が国の有人宇宙活動の将来展望」を設定した．

以下、特別講演，セッション講演，およびパネル討 論会ごとに，講演/討論の要旨をまとめることを通じ て, 我が国の有人宇宙技術の現状および問題点の解説 を試みたい.

\section{2. 特 別 講 演}

2.1 我が国の有人宇宙活動の将来展望（今井兼一 郎）我が国が 21 世紀を展望し，具体的に宇宙活動 を展開していくものとして，

(a) 宇宙科学研究の推進

(b) 宇宙利用の実用化の展開

(c) 宇宙インフラストラクチャーの構築と有人宇宙 活動の展開

（d）我が国の宇宙産業の展開 